\title{
Western diet induces endogen oxidative deoxyribonucleic acid damage and inflammation in Wistar rats
}

\author{
Dieta ocidental induz endógeno dano \\ oxidativo do ácido desoxirribonucleico \\ e inflamação em ratos Wistar
}

Yeşim YENER ${ }^{1}$ iD) 0000-0002-3344-6637

Fatma Hümeyra YERLIKAYA² (D) 0000-0002-4107-5389

\section{Objective}

Nutritional diseases such as metabolic syndrome, cardiovascular disorder, chronic inflammation or even cancer are observed in people who sustain their lifestyle by Western diet due to high calorie intake. The origin of these diseases are the degraded deoxyribonucleic acid structure. In this study, we investigated whether Western diet produced endogenous oxidative deoxyribonucleic acid damage, apoptosis or inflammation.

\section{Methods}

Twenty-eight male Wistar rats, aged 10-12 weeks, were divided into four groups. The rats in control group received the standard diet and the remaining rats were given one of the following three diets for four weeks: a high-fat diet containing 35\% fat, a high-sucrose diet containing 69\% sucrose and Western diet comprising both two types of diets. After treatment the serum 8-hydroxy-2-deoxyguanosine, poly (adenosine diphosphate ribose) polymerase-1, chitinase-3-like protein 1, soluble urokinase-type plasminogen activator receptor, Fas ligand and cytochrome c levels were measured.

\section{Results}

It was observed no changes in the serum soluble urokinase-type plasminogen activator receptor, Fas ligand and cytochrome c levels whereas a statistically significant increase in the serum 8-hydroxy-2-deoxyguanosine, poly (adenosine diphosphate ribose) polymerase-1 and chitinase-3-like protein 1 levels were found only in rats that were given Western diet.

1 Bolu Abant İzzet Baysal University, Faculty of Education, Department of Elementary Education. 14300, Gölköy, Bolu, Turkey. Correspondência para/Correspondence to: Y YENER. E-mail: <yesimyener77@gmail.com>.

2 Necmettin Erbakan University, Meram Faculty of Medicine, Department of Biochemistry. 42080, Meram, Konya, Turkey.

Como citar este artigo/How to cite this article

YENER Y, YERLİKAYA FH. Western diet induces endogen oxidative deoxyribonucleic acid damage and inflammation in Wistar rats. Rev Nutr. 2018;31(3):263-73. http://dx.doi.org/10.1590/1678-98652018000300001 


\section{Conclusion}

The findings show that Western diet produced endogenous oxidative deoxyribonucleic acid damage, which then increased serum poly (adenosine diphosphate ribose) polymerase-1 levels, eventually leading to inflammation.

Keywords: Apoptosis. Deoxyribonucleic acid. Inflammation. Diet western. Oxidative stress damage.

\section{RE S U M O}

\section{Objetivo}

Doenças nutricionais, como síndrome metabólica, distúrbios cardiovasculares, inflamação crônica ou mesmo câncer, são observadas em pessoas que sustentam seu estilo de vida na dieta ocidental, caracterizada pela alta ingestão de calorias. Dado que a origem dessas doenças é a estrutura degradada do ácido desoxirribonucleico, o presente estudo investigou se a dieta ocidental produzia dano oxidativo endógeno ao ácido desoxirribonucleico, apoptose ou inflamação.

\section{Métodos}

Foram utilizados 28 ratos Wistar machos, com idade entre 10-12 semanas, divididos em quatro grupos. Os ratos do grupo controle receberam a dieta padrão, ao passo que os ratos restantes receberam uma das três dietas seguintes por quatro semanas: uma dieta rica em gordura contendo 35\% de gordura; uma dieta rica em sacarose contendo 69\% de sacarose; e dieta ocidental compreendendo os dois tipos de dietas. Após o tratamento soro 8-hidroxi-2-desoxiguanosina, poli (adenosina difosfato ribose) polimerase-1, quitinase-3-like proteina 1, uroquinase solúvel tipo de receptor ativador de plasminogênio, os níveis do ligante Fas e do citocromo c foram medidos.

\section{Resultados}

Não foram observadas alterações nos níveis séricos de uroquinase solúvel tipo de receptor ativador de plasminogênio, ligante Fas e citocromo c, enquanto um aumento estatisticamente significativo nos níveis séricos de 8-hidroxi-2-desoxiguanosina, poli (adenosina difosfato ribose) polimerase-1 e quitinase-3-like proteína 1 foi encontrado apenas em ratos que receberam dieta ocidental.

\section{Conclusão}

Os resultados mostram que a dieta ocidental produziu danos no ácido desoxirribonucleico oxidativo endógeno, o que aumentou os níveis séricos de poli (adenosina difosfato ribose) polimerase-1, levando à inflamação.

Palavras-chave: Apoptose. Ácido desoxirribonucleico. Inflamação. Dieta ocidental. Dano oxidativo.

\section{INTROD UCTION}

The western diet, two important components of which is excess fat and excess sugar, is preferred by many people living in developed and developing countries. About $15-20 \%$ of the energy source of this diet comes from fructose. The most important source of fructose is sucrose (50\% glucose, 50\% fructose) and High Fructose Corn Syrup (HFCS), one of the energy-imparting sweetener. Many epidemiological, clinical and experimental studies have shown that due to the becoming the most used sweetener by the food industry over the last 30 years and its increasing consumption, fructose causes obesity, insulin resistance, impaired glucose tolerance, Type 2 diabetes, hyperlipidemia, hyperuricemia, gout, metabolic syndrome and cardiovascular diseases [1-3]. On the other hand, high fat intake with western diet is another contributing factor to the development of obesity and insulin resistance [4] and as a result, many studies have reported that this way of life is also closely related to cancer risk factors [5].

Actually the origin of these diseases are the degraded DNA structure. One of the molecules that cause this degradation is 8-hydroxy-2-deoxyguanosine (8-OHdG) which is an oxidative DNA lesion and it occurs as a result of hydroxylation of the deoxyguanosine residues in DNA by various agents [6]. Being a marker of oxidative DNA damage and having a mutagenic 
potential, 8-OHdG in leucocyte DNA or urine has also attracted the attention of researchers [7].

Poly (Adenosine Diphosphate [ADP]Ribose) polymerase (PARP) is an enzyme that catalyzes the polymerization of ADP-ribose units in target proteins in the cell nucleus [8]. PARP-1 detects single-strand breaks that occur as a result of oxidative DNA damage or under the usual base excision repair mechanism that occur under pathological conditions and in this process, this enzyme also repairs 8-OHdG lesions [9]. The inhibition of PARP-1 leads to the accumulation of single-strand breaks in DNA, which leads to double-strand breaks in the replication fork [10]. Such DNA damage in cells leads to apoptosis by inducing the production of p53 protein, activation of protease, and subsequent activation of endonucleases, catalyzing DNA fragmentation in internucleosomal regions [11].

Apoptosis occurs as a defense mechanism in immune reactions or when cells are damaged by disease or harmful substances. It can accrue in two basic pathways. The extrinsic pathway is located on the cell surface, mediated by death receptors and initiated by death receptors including Fas, a glycosylated protein activated by Fas Ligand (Fas L) [12]. The second is an organellecentric intrinsic pathway conducted by cysteine proteases, called caspase, and the basic caspase pathway in mammals is initiated by cytochrome c (Cyt c) [13]. Apoptosis is also triggered by inflammatory reactions that occur in cells or tissues, developing under both physiologic and pathologic conditions, as well as, in many cases, DNA damage induced by endogenous or exogenous sources in cells. Inflammation is a major contributor to many diseases, and the biological determination of inflammation is of significant benefit in determining the prognosis of the disease. In recent years, YKL-40 and suPAR have been extensively used as inflammatory biomarkers $[14,15]$.

YKL-40 is a plasma glycoprotein, also known as chitinase-3-like-1 or human cartilage glycoprotein-39. Although the specific function of YKL-40 is not fully known, it is thought that it stimulates the growth of fibroblasts [16]. In addition, YKL-40 is produced by local inflammatory cells, such as macrophages, neutrophils, endothelial and vascular smooth muscle cells in the inflamed region [14]. It plays a role in cases of angiogenesis, inflammatory processes, tissue destruction and apoptosis [17].

The urokinase-type Plasminogen Activator Receptor (UPAR) is the glycosylphosphatidylinositol (GPI)-anchor cell membrane receptor of serine protease urokinase-type plasminogen (UPA) [18]. Soluble UPAR (sUPAR) can be detected in blood, urinary and cerebrospinal fluid and involved in a variety of immunological conditions, including the plasminogen activation pathway, cell adhesion, migration, chemotaxis, proteolysis, and tissue regeneration [19]. In addition, suPAR has emerged as a relatively new biomarker that reflects increased inflammatory status and positively correlates with other inflammatory biomarkers [20].

It is known that following a fatty diet has an effect on the formation of oxidative damage, which is closely related to many pathological disorders, especially initiation and development of cancer. This study investigated whether the Western diet (a high-sucrose and highfat diet) produced endogenous oxidative DNA damage and how it affected the serum level of PARP-1 enzyme, responsible for repairing this damage. It is also known that prolonged DNA damage leads to apoptosis, and there is a close relationship between apoptosis and inflammation. Despite the availability of studies indicating that a high-fat diet induces apoptosis $[21,22]$, it is not known whether there is any relationship between endogenous DNA damage triggered by the Western diet or apoptosis and inflammation. Therefore, we aimed to examine the effect of this diet on endogenous oxidative DNA damage, apoptosis and inflammation. It is believed that the results of this study will present new approaches to the pathophysiology of diseases in people that have adopted the Western diet. 


\section{METHODS}

Twenty-eight adult male Wistar rats weighing $350 \pm 30 \mathrm{~g}$ and aged 10-12 weeks were obtained from Necmettin Erbakan University, KONÜDAM Experimental Medical Application and Research Center (Konya/Turkey). The application part of the study was carried out in the same center. The experimental animals were maintained in polycarbonate cages with seven animals per cage in a 12-hour light/dark cycle at a temperature of $20 \pm 2^{\circ} \mathrm{C}$ and humidity of $50 \%$. Food and tap water were provided as ad libitum.

\section{Experimental Procedure}

The animals were randomly and equally divided into four cages. The control group only received standard feed and tap water. The rats in the remaining three groups were given one of the following diets: a high-fat diet in which the total energy (kcal35\%) was supplied by suet [23], a high-sucrose diet in which 69\% of carbohydrate-derived energy content was provided by sucrose [24], and the Western diet, which was the combination of the high-fat and high-sucrose diets. For acclimatization, the animals were fed with high-fat or high-sucrose feed mixed with standard feed for three days. Then, for four weeks, the regime described for each group was followed. The feeds were obtained from a local firm (Nükleon Ltd., Ankara/ Turkey), and their composition is presented in Table 1.

\section{Sample analyses}

At the end of the application period, blood was taken from the animals by cardiac puncture under anesthesia administered intraperitoneally using ketamine $(60 \mathrm{mg} / \mathrm{kg})$ and xylazine $(10 \mathrm{mg} /$ $\mathrm{kg})$; then, the serum was separated from the blood samples to analyze the levels of 8-OHdG, PARP-1, Fas L, Cyt C, suPAR and YKL-40. Using commercially available kits and the EnzymeLinked Immunosorbent Assay (ELISA) method, the serum oxidative DNA damage and $8-\mathrm{OHdG}$ levels (DNA/RNA oxidative damage ELISA Kit, Cayman Chemical, and Ann Arbor, United States), and the serum PARP-1, Fas L, Cyt C, suPAR and YKL-40 levels (Rat ELISA Kit Instruction, Sunred Biological Technology, Shanghai, China) were measured.

\section{Statistical Analysis}

The data obtained from the experimental groups was analyzed by Statistical Package for the Social Sciences (SPSS Inc., Chicago, Illinois, United States) using the One-Way ANOVA

Table 1. Composition of experimental diet.

\begin{tabular}{|c|c|c|c|c|}
\hline Ingredients & Control (\%) & High sucrose diet (\%) & High fat diet (\%) & Western diet (\%) \\
\hline Sucrose & 10.00 & 69.00 & 10.00 & 69.00 \\
\hline Lipids & 3.00 & 3.20 & 35.80 & 35.10 \\
\hline Protein & 20.00 & 22.00 & 19.00 & 21.00 \\
\hline Calcium & 0.90 & 1.10 & 0.80 & 1.00 \\
\hline Fosfor & 0.60 & 0.58 & 0.59 & 0.57 \\
\hline Lysine & 0.95 & 1.36 & 1.24 & 0.58 \\
\hline Methionin & 0.40 & 0.45 & 0.42 & 0.41 \\
\hline Methionin + Cystin & 0.66 & 0.72 & 0.61 & 0.69 \\
\hline Sodium & 0.14 & 0.10 & 0.18 & 0.16 \\
\hline
\end{tabular}

Note: Lipid fraction of high fat and Western diet composition correspond to süet ( $38.4 \%$ saturated fatty acid, $44.8 \%$ monounsaturated fatty acid and $10.1 \%$ polyunsaturated fatty acid). 
test followed by the Tukey test. $p<0.05$ was considered statistically significant. All the results were expressed as mean \pm standard deviation.

The study was conducted in strict accordance with directive $86 / 609 / \mathrm{EEC}$ on the protection of laboratory animals. The Institutional Animal Care and Use Committee of Necmettin Erbakan University (Konya, Turkey) approved the study (Protocol Numbers: 2016-047, 0216-048, and 2016-049).

\section{RE S U L T S}

No sign of sickness, decreased activity or death was observed in any of the animals throughout the study period. The body weights of the animals were scored at the beginning and end of the study and no statistically significant difference was observed in the body weights of the animals in all dietary groups when compared with the control group at the termination of feeding procedure ( $p>0.05$, Table 2$)$.

The results concerning the effect of the Western diet on oxidative DNA damage and the level of PARP-1 are given in Table 3 and Figure 1. Serum YKL-40, SuPAR, Fas $L$ and Cyt c levels are also presented in Table 3 and shown in Figure 1.

There was no statistically significant increase in $8-\mathrm{OHdG}$ or PARP-1 in rats that had been given a high sucrose or high fat diet compared to the control group ( $p>0.05$ ). However, a statistically significant increase was found in both 8-OHdG and PARP-1 levels in the Western diet group compared to the other groups $(p<0.05)$. In relation to the effect of the Western diet on the remaining parameters, there was a statistically significant increase in the serum YKL-40 level in rats that had been given this diet $(p<0.05)$, but no statistically significant changes were observed in the serum levels of the remaining parameters (suPAR, Fas $L$ and Cyt c) ( $p>0.05)$.

In brief, a statistically significant increase was observed only in the serum 8-OHdG, PARP-1 and YKL-40 levels of that rats fed with the Western diet. The serum suPAR, Fas $L$, and Cyt c levels in the Western diet group were found to increase, but this was not statistically significant.

Table 2. The body weights of animals at the beginning and end of the study. (All values are mean \pm standart deviations).

\begin{tabular}{|c|c|c|c|c|c|c|c|c|c|c|c|c|}
\hline \multirow{2}{*}{ Body Weight Gain (g) } & \multicolumn{3}{|c|}{ Control } & \multicolumn{3}{|c|}{ High sucrose diet } & \multicolumn{3}{|c|}{ High fat diet } & \multicolumn{3}{|c|}{ Western diet } \\
\hline & M & & SD & M & & SD & $\mathrm{M}$ & & SD & M & & SD \\
\hline At the begening of the application & 267.43 & \pm & 11.2 & 255.0 & \pm & 18.7 & 265.0 & \pm & 9.9 & 250.0 & \pm & 37.9 \\
\hline At the end of the application & 339.14 & \pm & 16.9 & 342.7 & \pm & 61.7 & 343.86 & \pm & 11.7 & 355.8 & \pm & 34.5 \\
\hline
\end{tabular}

M: Mean; SD: Standard Deviation

Table 3. Serum 8-OHdG, PARP-1, YKL40, suPAR, Fas L and Cyt c levels of all groups (All values are mean \pm standart deviations).

\begin{tabular}{|c|c|c|c|c|c|c|c|c|c|c|c|c|}
\hline \multirow{2}{*}{ Parameters (ng/mL) } & \multicolumn{3}{|c|}{ Control } & \multicolumn{3}{|c|}{ High sucrose diet } & \multicolumn{3}{|c|}{ High fat diet } & \multicolumn{3}{|c|}{ Western diet } \\
\hline & M & & SD & M & & SD & M & & SD & M & & SD \\
\hline 8-OHdG & 1.55 & \pm & 0.32 & 1.68 & \pm & 0.29 & 1.59 & \pm & 0.36 & 2.34 & \pm & $0.89^{*}$ \\
\hline PARP-1 & 2.55 & \pm & 0.44 & 3.04 & \pm & 0.19 & 3.10 & \pm & 0.35 & 3.44 & \pm & $0.70^{*}$ \\
\hline YKL-40 & 6.59 & \pm & 0.35 & 7.14 & \pm & 0.25 & 6.74 & \pm & 0.38 & 7.26 & \pm & $0.55^{*}$ \\
\hline SUPAR & 3.29 & \pm & 0.50 & 3.31 & \pm & 0.24 & 3.46 & \pm & 0.17 & 3.96 & \pm & 1.23 \\
\hline Fas L & 2.84 & \pm & 0.25 & 2.96 & \pm & 0.16 & 2.73 & \pm & 0.17 & 3.15 & \pm & 0.31 \\
\hline Cyt C & 4.40 & \pm & 0.56 & 4.59 & \pm & 0.11 & 4.80 & \pm & 0.42 & 5.23 & \pm & 1.19 \\
\hline
\end{tabular}

${ }^{*} p<0.05$ compared to control group. M: Mean; SD: Standard Deviation. 


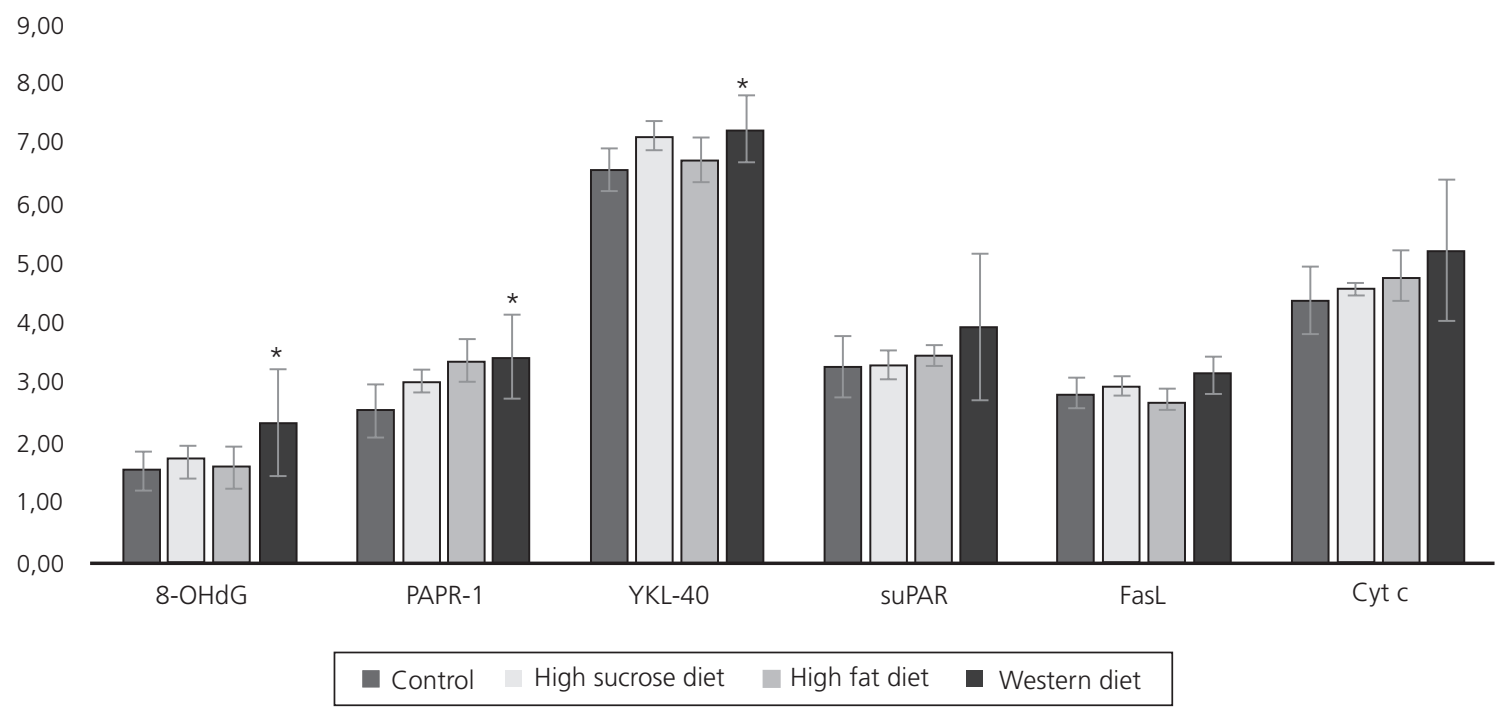

Figure 1. Changes in the levels of serum 8-OHdG, PARP-1, YKL-40, suPAR, Fas $L$ and Cyt c levels of rats in all groups. Note: ${ }^{*} p<0.05$ statistically different group when compared to the control and other groups.

\section{DISCUSSION}

The term "Western diet" is used to describe a modern diet, a product of industrial and agricultural revolutions in general and characterized by reduced dietary fiber, fruit and vegetable consumption, and increased fat and refined sugar [25]. Many epidemiological, clinical, and experimental studies have shown that diets containing high-fat or highsugar foods are associated with a variety of diseases and conditions, such as obesity, insulin resistance, impaired glucose tolerance, Type 2 diabetes, hyperlipidemia, cardiovascular disease, hyperuricemia, gout, and the metabolic syndrome $[26,27]$. Whether the diet is sugar or fat-welded, the excess energy intake causes an increase in acetyl-coenzyme A entering the Kreps cycle, leading to the overloading of the electron transport chain and the formation of Nicotinamide Adenine Dinucleotide (NAD) and superoxide anions in the mitochondria [25]. These superoxides pass through the anion channels and easily attack the sugars, proteins, lipids and DNA in the cytoplasm [28]. One of the reasons for the occurrence of oxidative DNA damage is that these free radicals attack the deoxyribose, which usually leads to breaking a single strand of DNA. If these single-strand breaks are not successfully repaired, they can cause doublestrand breaks, which can lead to cell death. The indication of an oxidized DNA is the detection of 8-OHdG in the blood or urine, which provides important clues to lifestyle-related diseases. In recent years, significant increases in serum or urine $8-\mathrm{OHdG}$ levels have been shown in various cancer patients. For example, in a study by Kumamoto et al. [29], in which the sugar content of diets applied to the rats was $66 \%$ and the application period was eight weeks, it was found that the frequency of experimentally induced pre-cancerous hepatocytes in rats fed with high-fat / high-sugar diets was increased by the induction of insulin resistance and oxidative stress. In the current study, the application period was not as long but oxidative DNA damage was observed not only in rats given high-fat or only high-sucrose diet but also in those that received a Western diet (Table 3, Figure 1).

PARP-1 is an enzyme responsible for repairing single-strand breaks, and in this process, this enzyme also repairs $8-\mathrm{OHdG}$ lesions [9]. So that the increase these lesions also increases the activation of PARP-1 under pathophysiological conditions affecting DNA 
[30]. In the current study, it was determined that both the serum PARP-1 and 8-OHdG levels increased significantly in rats fed with a Western diet (Table 3, Figure 1). This finding indicates that the Western diet caused oxidative DNA damage, which in turn elevated the PARP-1 molecules to repair this damage. PARP-1 also plays a role in multiple cellular processes, such as DNA replication, transcriptional regulation, chromatin modification, apoptosis and inflammation, as well as repairing DNA damage [31,32]. The inflammatory process of PARP-1 is mediated by a variety of mechanisms, including transcription factors, cytokines, adhesion factors, and regulation of inflammatory mediators [33]. The effect of PARP-1 on transcription factors is either through direct interaction or by altering their activity through PARylation. By adding ADP-ribose chains to target proteins using NAD + or itself as a donor, PARP-1 performs the PARylation process [32]. Furthermore, PARP-1 provides PARylation of the well-defined transcription factor Nuclear Factor kappa B (NFKB) and is a co-activator of NFKB [34]. The inhibition of PARP-1 eliminates the NF-KB signal, thus resulting in reduced inflammatory response [32]. This inhibition has been shown to have beneficial effects in inflammatory diseases, such as diabetes, asthma and atherosclerosis [35]. Inflammation is triggered not only by PARP-1 but also by the production of reactive oxygen radicals due to the excessive energy uptake activating redox-sensitive transcription factors. This creates numerous cascade effects, including the inflammatory process [25], as well as many redox-sensitive transcription factors, including NFkB, Activator Protein 1 (AP-1) and Early Growth Response 1 (EGR1), which are known to cause cellular and systemic inflammation, and formation of oxidative stress [36]. NFkB, the result of transcription, mediates the release of inflammatory cytokines, such as tumor necrosis factor alpha (TNFa) and interleukin-6 (IL-6) $[37,38]$. The release of these cytokines induces the expression of YKL-40 by macrophages [25]. This expression is also induced by other proinflammatory cytokines such as interleukin-3
(IL-3), interferon-gamma (IFN-y), vasopressin and parathyroid hormone [39]. During the release of YKL-40 by macrophages, monocytes and macrophages accumulate in the fatty tissue and change their nature over time, and during the reshaping of the tissues, the fatty tissue may transform into an endocrine organ that can further mediate inflammation [36]. Agus et al. [40] emphasized that a specific inflammatory environment was created in the intestine associated with the intestinal mucosa of rats fed with a high-fat and high-sugar diet. Collins et al. [41] reported an increase in the number of proinflammatory cells in rats fed with high fat and high sugar for three days. Yang et al. [42] showed that the expression of mRNAs of genes involved in inflammation and lipid metabolism in liver and white fat tissue increased from the second week onwards in mice fed with high fat and high sugar. In our study, the levels of proinflammatory cytokines that induce the release of YKL-40 from macrophages were not examined, but the level of PARP-1 inducing the expression of NFkB-dependent proinflammatory cytokines, such as TNFa, IL-6 and inducible nitrite oxidase (iNOS) was measured and found to be increased by the Western diet. There are also studies showing that the Western diet leads to an increase in these cytokines [43]. Thus, it is likely that this increase in the serum YKL-40 levels of rats fed with the Western diet may have been induced by an increase in the levels of these cytokines. This increase may also have been caused by DNA damage induced by this type of diet since endogenous DNA damage activates IFN-stimulated genes, particularly interferon-alpha (IFN- $a$ ) and interferon-lambda (IFN- $\lambda$ ) [44]. Our findings showed that excessive energy uptake with the Western diet leads to endogenous DNA damage, and this triggers the expression of inflammatory genes and, at the same time, increases the level of PARP-1 molecules to repair the damage. In addition, increased PARP-1 molecules have been shown to activate proinflammatory cytokines, thereby inducing the release of YKL-40 from macrophages, thus contributing to the inflammatory process (Figure 
2). In our study, it was also examined that the level of sUPAR, another inflammation marker, increased only in rats fed with the Western diet, but this was not statistically significant. When

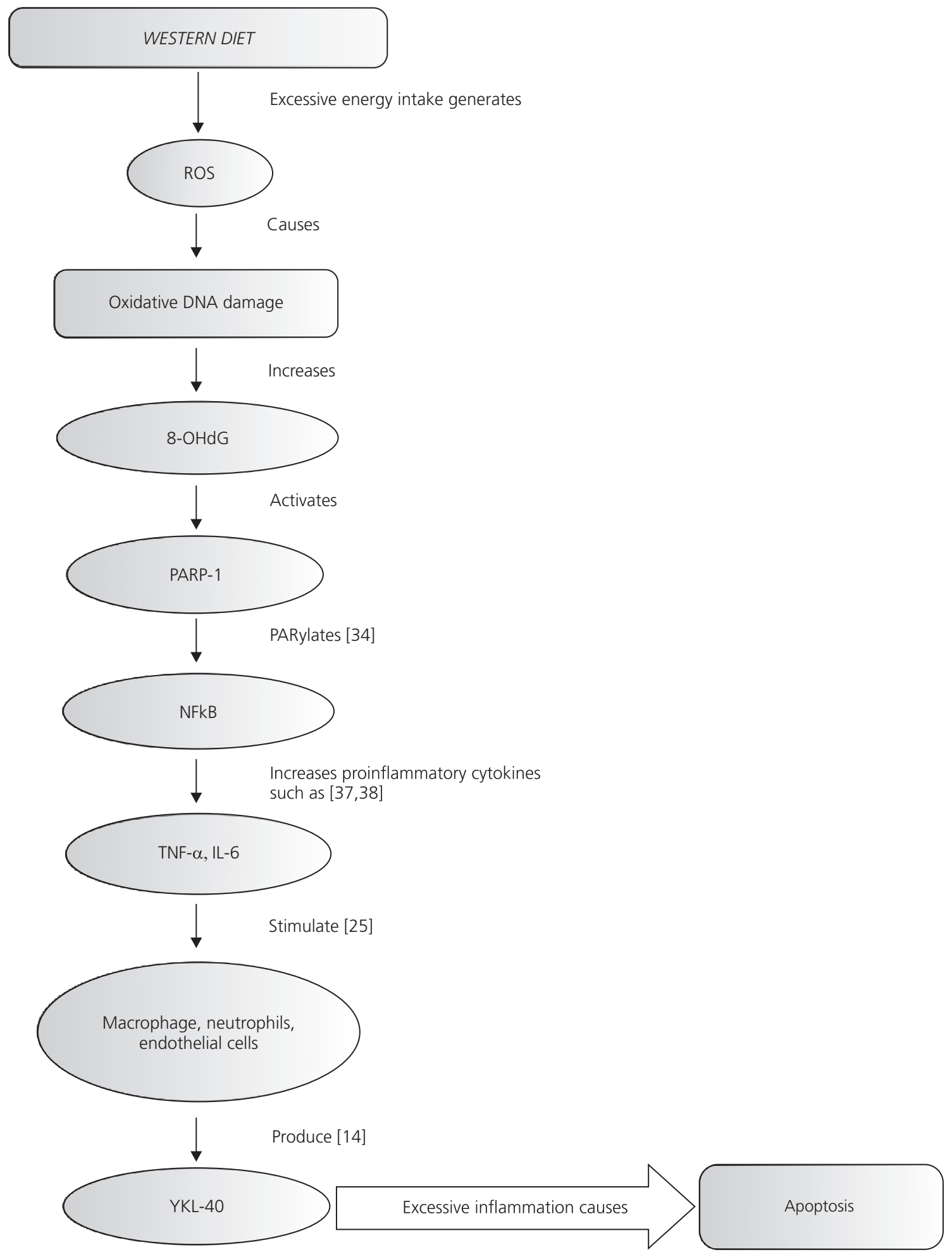

Figure 2. Probable downstream cascade caused by Western diet. 
compared with the change in the serum YKL-40 level in the same application period, it can be interpreted that suPAR reacts later than YKL-40 in the inflammation process, and therefore, the latter is a more sensitive marker for determining inflammation.

It is known that apoptosis plays an important role in inflammatory processes and in the resolution of inflammatory reactions. Apoptotic cells must be quickly removed by macrophages, which is a critical step in the termination of inflammation. The phagocytosis of apoptotic cells actively suppresses inflammation by inhibiting the production of inflammatory cytokines and inducing the production of antiinflammatory agents, such as TGF- $\beta$ and prostaglandin E2 [45]. However, some studies have suggested that a Western diet reduces the production of antiapoptotic BCl-2 protein [46] and a high-fat diet triggers apoptosis $[21,22,47]$. It was observed in our study that the serum levels of apostotis markers, namely Fas $L$ and Cyt c were increased only in rats fed with the Western diet with no statistical significance. If this type of diet is maintained, it is probable that apoptosis will be triggered as a result of endogen DNA damage and inflammation induced by the excessive energy intake in the Western diet.

\section{CONCLUSION}

The results of this study showed that the Western diet produces endogenous oxidative DNA damage, which activates PARP-1 and forms molecules in the pathway, leading to inflammation. If this inflammation is excessive, it may result in apoptosis. Continued consumption of this diet may trigger the development of a variety of diseases, including cancer. Further research is needed to support this idea. It is considered that the findings obtained from this study can be used to develop new approaches to the pathophysiology of diseases accompanied by the Western diet.

\section{ONTRIBUTOR S}

The design of the study, the application phase, and the literature search phase were done by all authors, and article review and the format of the article was taken by $Y$ YENER.

\section{REFERENCES}

1. Niu L, Han DW, Xu RL, Han B, Zhou X, Wu $H W$, et al. A high-sugar high-fat diet induced metabolic syndrome shows some symptoms of Alzheimer's disease in rats. J Nutr Health Aging. 2016;20(5):509-13.

2. Pranprawit A, Wolber FM, Heyes JA, Molan AL, Kruger MC. Short-term and long-term effects of excessive consumption of saturated fats and/or sucrose on metabolic variables in Sprague Dawley rats: A plot study. J Sci Food Agric. 2013;93(13):3191-7.

3. Sonestedt E, Øverby NC, Laaksonen DE, Birgisdottir $\mathrm{BE}$. Does high sugar consumption exacerbate cardiometabolic risk factors and increase the risk of type 2 diabetes and cardiovascular disease? Food Nutr Res. 2012;56:1-19.

4. Kumar R, Litoff EJ, Boswell WT, Baldwin WS. High fat diet induced obesity is mitigated in Cyp3a-null female mice. Chem Biol Interact. 2018;289:129-40.

5. Harris KL, Pulliam SR, Okoro E, Guo Z, Washington $\mathrm{MK}$, Adunyah $\mathrm{SE}$, et al. Western diet enhances benzo(a)pyrene-induced colon tumorigenesis in a polyposis in rat coli (PIRC) rat model of colon cancer. Oncotarget. 2016;7(20):28947-60.

6. Evans MD, Dizdaroglu M, Cooke MS. Oxidative DNA damage and disease: Induction, repair and significance. Mutat Res. 2004;567(1):1-61.

7. Gordillo G, Fang H, Park H, Roy S. Nox-4Dependent nuclear $\mathrm{H} 2 \mathrm{O} 2$ drives DNA oxidation resulting in $8-\mathrm{OHdG}$ as urinary biomarker and hemangioendothelioma formation. Antioxid Redox Signal. 2010;12(8):933-43.

8. Ame J, Rolli V, Schreiber V, Niedergang C, Apiou F, Decker $\mathrm{P}$, et al. PARP-2, a novel mammalian DNA damagedependent poly(ADP-ribose) polymerase. J Biol Chem. 1999;274(25):17860-8.

9. Martín-Oliva D, Martín-Guerrero SM, MatiaGonzález AM, Ferrer-Martín RM, Martín-Estebané $\mathrm{M}$, Carrasco MC, et al. DNA damage, poly(ADPribose) polymerase activation, and phosphorylated histone H2AX expression during postnatal retina development in C57BL/6 mouse. Invest Ophthalmol Vis Sci. 2015;56(2):1301-9.

10. McCabe N, Turner NC, Lord CJ, Kluzek K, Białkowska A, Swift S, et al. Deficiency in the repair 
of DNA damage by homologous recombination and sensitivity to poly(ADP-ribose) polymerase inhibition. Cancer Res. 2006;66(16):8109-15.

11. Thompson CB. Apoptosis in the pathogenesis and treatment of disease. Science. 1995;267(5203):1456-62.

12. Akazawa Y, Gores GJ. Death receptor-mediated liver injury. Semin Liver Dis. 2007;27(4):327-38.

13. Jiang X, Wang X. Cytochrome C-mediated apoptosis. Annu Rev Biochem. 2004;73:87-106.

14. Kjaergaard AD, Johansen JS, Bojesen E, Nordestgaard BG. Role of inflammatory marker YKL-40 in the diagnosis, prognosis and cause of cardiovascular and liver diseases. Crit Rev Clin Lab Sci. 2016;53(6):396-408.

15. Kosecik M, Dervisoglu P, Koroglu M, Isguven $P$, Elmas B, Demiray $T$, et al. Usefulness of soluble urokinase plasminogen activator receptor (suPAR) as an inflammatory biomarker in obese children. Int J Cardiol. 2017;228:158-61.

16. Recklies $A D$, White $C$, Ling $H$. The chitinase 3-like protein human cartilage glycoprotein 39 (HC-gp39) stimulates proliferation of human connective tissue cells and activates both extracellular signal-regulated kinase- and protein kinase B-mediated signalling pathways. Biochem J. 2002;365(Pt1):119-26.

17. Johansen JS, Bojesen SE, Tybjaerg-Hansen A, Mylin AK, Price PA, Nordestgaard BG. Plasma YKL-40 and total and disease-specific mortality in the general population. Clin Chem. 2010;56(10):1580-91.

18. Hoyer-Hansen G, Lund IK. Urokinase receptor variants in tissue and body fluids. Adv Clin Chem. 2007;44:65-102.

19. Donadello K, Scolletta S, Covajes C, Vincent JL. su-PAR as a prognostic biomarker in sepsis. BMC Med. 2012;10:2. http://dx.doi.org/10.1186/1741-70 15-10-2

20. Persson M, Engström G, Björkbacka H, Hedblad B. Soluble urokinase plasminogen activator receptor in plasma is associated with incidence of CVD: Results from the Malmö Diet. Atherosclerosis. 2012;220(2):502-5.

21. Moraes JC, Coope A, Morari J, Cintra DE, Roman EA, Pauli JR, et al. High-fat diet Induces apoptosis of hypothalamic neurons. Plos ONE. 2009;4(4):e5045. http://dx.doi.org/10.1371/journal. pone.0005045

22. Wang Y, Ausman LM, Russell RM, Greenberg AS, Wang XD. Increased apoptosis in high-fat diet-induced nonalcoholic steatohepatitis in rats is associated with c-Jun NH2-terminal kinase activation and elevated proapoptotic Bax. J Nutr. 2008;138(10):1866-71.
23. Bravo R, Cubero J, Franco L, Mesa M, Galán C, Rodriguez $A B$, et al. Body weight gain in rats by a high-fat diet produces chronodisruption in activity/inactivity circadian rhythm. Chronobiol Int. 2014;31(3):363-70.

24. Garg M, Mehra P, Bansal DD. Hormonal imbalance and disturbances in carbohydrate metabolism associated with chronic feeding of high sucrose low magnesium diet in weanling male wistar rats. Mol Cell Biochem. 2014;389(1-2):35-41.

25. MuñozA, Costa M. Nutritionally mediated oxidative stress and inflammation. Oxid Med Cell Longev. 2013:6 http://dx.doi.org/10.1155/2013/610950

26. Bhatta A, Yao L, Toque HA, Caldwell RB, Caldwell RW. High fat-high sucrose diet induced vascular endothelial dysfunction, fibrosis and stiffness involve elevated arginase activity. Faseb J. 2016;30(Suppl1).

27. Hou L, Li F, Wang Y, Ou Z, Xu D, Tan W, et al. Association between dietary patterns and coronary heart disease: A meta-analysis of prospective cohort studies. Int J Clin Exp Med. 2015;8(1):781-90.

28. Andreyev AY, Kushnareva YE, Starkov AA. Mitochondrial metabolism of reactive oxygen species. Biochem. 2005;70(2):200-14.

29. Kumamoto R, Uto H, Oda K, Ibusuki R, Tanoue $S$, Arima $S$, et al. Dietary fructose enhances the incidence of precancerous hepatocytes induced by administration of diethylnitrosamine in rat. Eur J Med Res. 2013;18:54. http://dx.doi. org/10.1186/2047-783X-18-54

30. Ding W, Liu W, Cooper KL, Qin XJ, Souza-Bergo $\mathrm{PL}$, Hudson LG, et al. Inhibition of Poly(ADP-ribose) Polymerase- 1 by Arsenite Interferes with Repair of Oxidative DNA Damage. J Biol Chem. 2008;284(11):6809-17.

31. Hassa PO, Hottiger MO. The diverse biological roles of mammalian PARPS, a small but powerful family of poly-ADP-ribose polymerases. Front Biosci. 2008;13:3046-82.

32. Swindall AF, Stanley JA, Yang ES. PARP-1: Friend or foe of DNA damage and repair in tumorigenesis? Cancers. 2013;5(3):943-58.

33. Liu L, Ke $Y$, Jiang $X$, He F, Pan $L$, Xu L, et al. Lipopolysaccharide activates ERK-PARP-1-ReIA pathway and promotes nuclear factor-kappaB transcription in murine macrophages. Hum Immunol. 2012;73(5):439-47.

34. Hassa PO, Hottiger MO. A role of poly (ADP-ribose) polymerase in NF-kappaB transcriptional activation. Biol Chem. 1999;380(7-8):953-9.

35. Giansanti V, Dona F, Tillhon M, Scovassi Al. PARP inhibitors: New tools to protect from inflammation. Biochem Pharmacol. 2010;80(12):1869-77. 
36. Iyer A, Fairlie DP, Prins JB, Hammock BD, Brown L. Inflammatory lipid mediators in adipocyte function and obesity. Nat Rev Endocrinol. 2010;6(2):71- 82.

37. Oliver FJ, Menissier-de Murcia J, Nacci C, Decker P, Andriantsitohaina R, Muller S, et al. Resistance to endotoxic shock as a consequence of defective NF-kappaB activation in poly (ADPribose) polymerase-1 deficient mice. EMBO J. 1999;18(16):4446-54.

38. Patel C, Ghanim H, Ravishankar S, Sia CL, Viswanathan P, Mohantym P, et al. Prolonged reactive oxygen species generation and Nuclear Factor-kB activation after a high-fat, highcarbohydrate meal in the obese. J Clin Endocrinol Metab. 2007;92(11):4476-9.

39. Johansen JS. Studies on serum YKL-40 as a biomarker in diseases with inflammation, tissue remodelling, fibroses and cancer. Dan Med Bull. 2006;53(2):172-209.

40. Agus A, Denizot J, Thévenot J, Martinez-Medina M, Massier S, Sauvanet $P$, et al. Western diet induces a shift in microbiota composition enhancing susceptibility to Adherent-Invasive $E$. coli infection and intestinal inflammation. Sci Rep. 2016;6:19032. http://dx.doi.org/10.1038/srep19 032

41. Collins KH, Paul HA, Hart DA, Reimer RA, Smith IC, Rios JL, et al. A High-fat high-sucrose diet rapidly alters muscle integrity, inflammation and gut microbiota in male rats. Sci Rep. 2016,6:37278. http://dx.doi.org/10.1038/srep37278
42. Yang ZH, Miyahara HM, Takeo J, Katayama M. Diet high in fat and sucrose induces rapid onset of obesity-related metabolic syndrome partly through rapid response of genes involved in lipogenesis, insulin signalling and inflammation in mice. Diabetol Metab Syndr. 2012;4:32. http:// dx.doi.org/10.1186/1758-5996-4-32

43. Guo X, Li J, Tang R, Zhang G, Zeng H, Wood RJ, et al. High Fat diet alters gut microbiota and the expression of paneth cell-antimicrobial peptides preceding changes of circulating inflammatory cytokines. Mediators Inflamm. 2017;2017:1-9. http://dx.doi.org/10.1155/2017/9474896

44. Brzostek-Racine S, Gordon C, Van Scoy S, Reich NC. The DNA damage response induces interferon. J Immunol. 2011;187(10):5336-45.

45. Henson PM, Bratton DL. Antiimflammatory effects of apoptotic cells. J Clin Invest. 2013;123(7):2773-4.

46. Ballal K, Wilson CR, Salazar RL, Taegtmeyer $H$. Western diet induces apoptosis in the heart of a rat model with diet-induced obesity. Faseb J. 2008;22(Suppl1).

47. Hsu HC, Chen CY, Lee BC, Chen MF. High-fat diet induces cardiomyocyte apoptosis via the inhibition of outophagy. Eur J Nutr. 2016;55(7):2245-54.

Received: April 17, 2018

Final version: July 12, 2018 Approved: August 2, 2018 